\title{
THE MAIN PARAMETERS OF IRON METABOLISM IN PATIENTS WITH UROTELIAL BLADDER CANCER AT DIFFERENT DEVELOPMENT STAGES OF MALIGNANT NEOPLASM ANEMIA
}

\author{
Dmytro Borysenko \\ Postgraduate Student, Shupyk National Medical Academy of Postgraduate Education, Ukraine \\ e-mail: borysenko_d@ukr.net,orcid.org/0000-0003-4726-1235
}

\section{Stanislav Vydyborets}

M.D., Professor, Shupyk National Medical Academy of Postgraduate Education, Ukraine e-mail: vydyborets57@gmail.com,orcid.org/0000-0003-0546-4325

\section{Summary}

The article presents information about the protein responsible for the iron depot in the body - ferritin. Its physiological role and clinical significance are demonstrated. A batophenanthroline method was used to determine the range of iron in the blood serum and the range of the total iron-binding capacity of the blood serum. The range of unsaturated iron-binding capacity of blood serum was calculated as the difference between total iron-binding capacity in blood serum and the range of iron in blood serum. The transferrin saturation coefficient of iron was defined as the ratio of the content of iron in blood serum to the total iron-binding capacity in blood serum. The range of transferrin was determined by the rate of the total iron-binding capacity in blood serum, and ferritin using the radiometric method. The dynamics of changes in ferritin content in malignant neoplasm anemia in patients with bladder cancer has been demonstrated. The conclusion about the importance of this parameter for laboratory diagnosis of iron deficiency and anemia of malignant neoplasms is made.

Keywords: ferritin, physiological role, clinical significance, blood serum.

DOI https://doi.org/10.23856/4332

\section{Introduction}

Bladder cancer is one of the ten most common diseases of the urinary system of non-plastic nature, and given its prevalence, it is second only to prostate cancer (Titov, 2018). Among the entire population of Ukraine, the incidence range of malignant neoplasms of the bladder in the years 2012-2018 ranged from 9,7 to 11,4 per 100 thousand population. And among the male population of Ukraine, this range was significantly higher and ranged from 17,1 to 19,8 per 100 thousand population (Linchevskii, 2019). Urotelial bladder cancer is the most common non-plastic form of this organ and in percentage terms reaches almost $90 \%$. In three-quarters of cases, urotelial bladder cancer is detected in stages Ta and T1 (non-invasive stages), but as clinicians note, the results of treatment in non-invasive stages do not always give the expected outcome. There is a significant number of methods and algorithms for diagnosis and prognosis, but they require further improvement (Fedorenko, 2019, Linchevskii, 2019). Recommendations of the European Society of Oncologists (2018) for the management of patients with malignant neoplasm anemia have been developed.

The main function of ferritin is considered to be the binding and accumulation (deposition) of iron in a physiologically accessible, non-toxic form for the body (Wick, 1995). This 
function of ferritin is well studied. It provides, if necessary, the mobilization of iron for the synthesis of hemoglobin, other heme-containing, and non-heme iron-containing compounds. The main iron-depositing function in the body is performed by the ferritin of the liver. Ferritin of the mucous membrane of the small intestine is responsible for the transfer of absorbed iron into enterocytes, and then to plasma transferrin. Ferritin of phagocytic macrophages system absorbs iron that is released after the destruction of erythrocytes and iron-containing compounds, for the processes of its reutilization. Ferritin of erythroid progenitor cells provides adequate iron supply for hematopoiesis. Ferritin of the spleen plays a depositing role and provides the transition of iron to plasma transferrin (Green, 2014). Ferritin is synthesized by cells of the liver, spleen, bone marrow, small intestine, pancreas, kidneys, lungs, thyroid gland, placenta as well as leukocytes. Synthesized in various organs, ferritin is used by them to function, however, in small quantities, it enters the blood plasma. In the state of physiological equilibrium, the level of ferritin in plasma correlates with iron stores in the body (Wick, 1995). It was found that in the blood serum of an adult $1 \mu \mathrm{g} / \mathrm{l}$ ferritin is normally equivalent to about $8 \mathrm{mg}$ of deposited iron. In healthy adults, the level of ferritin in the blood serum depends on gender and, to a lesser extent, on age (Popovych, 2020). Women of reproductive age have a blood serum ferritin level of $10-90 \mu \mathrm{g} / \mathrm{l}$, and men $-30-200 \mu \mathrm{g} / \mathrm{l}$. In the postmenopausal period, the level of ferritin for women is equal to that for men of the same age. The level of ferritin in the blood serum of children increases during the first three months after birth, and after 6 months and before puberty does not change, varying in the range of 8-84 $\mu \mathrm{g} / 1$ (Wick, 1995). There are circadian rhythms of changes in ferritin levels of blood serum.

Currently, the problem of malignant neoplasm anemia is being actively studied, and the very nosological form of this anemia is included in the International Classification of Diseases (ICD) under the code D63.0. In the available scientific literature, we have not found studies of generalizing and research nature, which from the standpoint of modern vision, would cover the relationship of glycolytic processes in peripheral blood erythrocytes, ferritin metabolism, and the emergence and development of malignant neoplasm anemia in patients with urothelial bladder cancer. So this prompted us to conduct relevant research.

The purpose of the research was to study peripheral blood parameters, plasma iron metabolism parameters in patients with malignant neoplasm anemia having urotelial bladder cancer, to trace the relationship of their changes with the ferritin rates in blood plasma, to evaluate the possible diagnostic and prognostic value of the detected changes.

\section{Material and methods of research}

The material for the study was the blood of 96 patients (64 men and 32 women) with bladder cancer, among them were 39 patients (28 men and 11 women) who did not have anemia during the underlying disease (first (I) observation group) and 57 patients (36 men and 21 women) who had malignant neoplasm anemia during the underlying disease (second (II) observation group). 45 patients (19 men and 26 women) were examined separately. They had iron deficiency anemia, the cause of which was chronic blood loss (third (III) observation group). The age of the study group ranged from 22 to 69 years. All patients were examined after verification of the diagnosis and before the administration of any treatment.

The severity of anemia was determined according to the criteria proposed by the National Cancer Institute (USA) and distinguished as: mild (Grade 1), Hb from 10-12 g/dL; moderate (Grade 2), Hb 8,0-10,0 g/dL; severe (Grade 3), Hb 6,5-8 g/dL to 6,5 g/dl; life-threatening (Grade 4), Hb <6,5 g/dL. 29 patients were diagnosed with mild severity of malignant neoplasm 
anemia, 12 patients with moderate, 10 patients with severe, and 6 had a life-threatening severity. Respectively 19 patients with iron deficiency anemia had mild severity, 14 patients had moderate, 7 patients had severe and life-threatening severity had 5 patients.

All studies were carried out in compliance with the main provisions of the Council of Europe Convention on Human Rights and Biomedicine, World Medical Association Declaration of Helsinki on Ethical Principles for Medical Research with Human Participation (1964 with subsequent amendments, including version 2000), and Order of the Ministry of Health of Ukraine No. 690 dated 23.09.2009. Upon admission to the hospital, all patients were examined using clinical, laboratory, instrumental and special research methods, if necessary, they were consulted by specialists of related specialties. The examination and treatment of patients were performed following the World Medical Association Declaration of Helsinki (Seoul, 2008), and the relevant orders of the Ministry of Health of Ukraine (No. 281 from 01.11. 2000, No. 355 from 25.09.2002, No. 356 from 22.05.2009 in the revision of the Ministry of Health of Ukraine Order No. 574 of 5 August 2009, No. 1118 of 21 December 2012).

The control group consisted of 50 healthy primary donors who had no history of oncological or chronic inflammatory diseases. All donors were examined at the State Institution "Blood Transfusion Station of the Southwestern Railway" following the requirements of the "Procedure of medical examination of blood donors and (or) its components", approved by the Order of the Ministry of Health of Ukraine dated 01.08.2005 under No. 385 "On infectious safety of donor blood and its components".

The range of iron in blood serum and total iron-binding capacity in blood serum were determined by the batophenanthroline method. The range of the unsaturated iron-binding capacity of blood serum was calculated as the difference between the total iron-binding capacity in blood serum and the range of iron in blood serum. Iron transferrin saturation coefficient was defined as the ratio of the range of iron in blood serum to the total iron-binding capacity in blood serum. The range of transferrin was determined by the total iron-binding capacity of blood serum, the range of ferritin was determined by the radiometric method.

A careful histological examination of the drugs was performed for patients with urothelial bladder cancer. We took into account the nature of the margins of the tumor with the surrounding tissues, the severity of infiltration, the presence of tumor cells in the vessels, the number of mitoses, including atypical ones. Also, we determined in tumors cell elements of different degrees of maturity (in \%) - low-differentiated, moderately differentiated, highly differentiated cells. According to generally accepted criteria, the degree of malignancy and histological type of tumor was assessed.

The research results were statistically processed according to the relevant programs (Khalafian, 2014). The reliability of the difference was assessed using the Student's difference coefficient $(\mathrm{p}<0,05)$.

\section{Results and its discussion}

According to the analysis of the results of the peripheral blood study in patients, the hemoglobin concentration in patients of groups II and III was significantly lower than in the control group and group I $(\mathrm{p}<0,001)$. The control group had this range on average $(142,72 \pm$ $\pm 4,60) \mathrm{g} / 1$, while women had $131,06 \pm 3,77 \mathrm{~g} / 1$, with individual fluctuations from 125 to $147 \mathrm{~g} / \mathrm{l}$. Men had a higher hemoglobin concentration than women $(\mathrm{p}<0,001)$. At the same time, for patients of groups II and III, we did not find significant differences in hemoglobin concentration depending on gender $(\mathrm{p}>0,05)$. 
The number of erythrocytes in the control group was $(4,76 \pm 0.15) \times 10^{12} / 1$ on average. At the same time, this range for men averaged $(4,86 \pm 0.15) \times 10^{12} / 1$, and for women, it was $(4,38 \pm 0,13) \times 10^{12} / 1$, with individual fluctuations for men - from 4,4 to $5,0 \times 10^{12} / 1$, and for women - from 4,2 to $4,7 \times 10^{12} / 1$. The number of erythrocytes in the control group with men was higher than the control group with women $(\mathrm{p}<0,001)$. At the same time, for patients of groups II and III, we did not find significant differences in the number of erythrocytes depending on gender $(\mathrm{p}>0,05)$.

The range of leukocytes in the control group with men, on average, was $(5,85 \pm 1,24) \times$ $\times 10^{9} / 1$, with individual fluctuations from 3,9 to $7,3 \times 10^{9} / 1$, and in the control group with women $-(5,83 \pm 1,32) \times 10^{9} / 1$, with individual fluctuations from 3,8 to $8,3 \times 10^{9} / 1$. We did not find significant differences in this range in the examined groups of patients in comparison with the control group, as well as differences depending on gender $(\mathrm{p}>0,05)$.

The number of platelets in the control group, on average, was $(203,40 \pm 13,94) \times 10^{9} /$ liter. This range for men averaged $(204,38 \pm 15,23) \times 10^{9} / 1$, and for women, it was $(201,67 \pm 11,51) \times$ $\times 10^{9} / 1$, with individual fluctuations for men - from 180 to $230 \times 10^{9} / 1$, and for women - from 190 to $220 \times 10^{9} / 1$. A comparative analysis of these ranges showed that it was higher in patients of groups II and III compared with the control group $(p<0,001)$. This fact may confirm the idea of the presence of overt or covert bleeding in patients of groups II and III with a compensatory enhancement of hematopoiesis in the myelocyte sprout, in particular, thrombocytopoiesis.

The range of reticulocytes in the control group, on average, was $(0,88 \pm 0,05) \%$, in men $-(0,87 \pm 0,05)$, and for women $-(0,88 \pm 0,04) \%$. We found that in patients of group II this range was significantly lower than in the control group, groups I and III $(p<0,001)$. This, in our opinion, can be explained by the suppression of erythropoiesis in patients with malignant neoplasm anemia by exposure to humoral factors and intoxication syndrome.

The range of $\mathrm{MCH}$ in the control group was $(30,63 \pm 0,25) \mathrm{pg}$, with fluctuations from 27 to $33 \mathrm{pg}$. For women, this range averaged $(29,40 \pm 0,42) \mathrm{pg}$, with individual fluctuations from 27 to $31 \mathrm{pg}$, and for men, respectively was $(31,13 \pm 0,24) \mathrm{pg}$, with individual fluctuations from 28 to 33 p.m. There were no significant differences in the $\mathrm{MCH}$ range for this group depending on gender $(p>0,05)$. A comparative analysis of this range showed that it was lower for patients of groups II and III compared with the control group $(p<0,001)$. This fact indicates that patients of groups II and III have disorders of hemoglobin synthesis and iron deficiency. It can be assumed that in group III it occurs due to chronic blood loss, and in group II, apparently, due to increased levels of pro-inflammatory interleukins and hepcidin.

The MCV range in the control group was $(93,41 \pm 0,91) \mathrm{fl}$, with fluctuations from 84 to $97 \mathrm{fl}$. For women, this range averaged $(94,22 \pm 1,69) \mathrm{fl}$ with individual fluctuations from 89 to $97 \mathrm{fl}$, and for men it was $(92,29 \pm 1,01) \mathrm{fl}$, with individual fluctuations from 84 up to $96 \mathrm{fl}$. We did not find significant differences in the MCV range in group I compared with the control group $(p>0,05)$, at the same time, we found a decrease in the range in groups II and III $(\mathrm{p}<0,001)$.

The range of $\mathrm{MCHC}$ in the control group was $(34,38 \pm 0,23) \%$, with fluctuations from 33 to $35 \%$. For women, the range of $\mathrm{MCHC}$, on average, was $(34,35 \pm 0,31) \%$ with individual fluctuations from 33 to $35 \%$, and for men, on average it was $(34,41 \pm 0,41) \%$, with individual fluctuations indicator from 33 to $35 \%$. We did not find significant differences in the rate of $\mathrm{MCHC}$ among patients of group I compared with the control group $(\mathrm{p}>0,05)$. We found a decrease in the range of MCHC among patients of groups II and III ( $p<0,001)$, which reflects the presence of disorders of iron metabolism and erythropoiesis, and hemoglobin synthesis.

The main ranges of iron metabolism among the study groups are shown in table 1. 
Table 1

The main ranges of iron metabolism in the study groups $(\mathrm{M} \pm \mathrm{m})$

\begin{tabular}{|c|c|c|c|c|c|}
\hline \multirow[b]{2}{*}{$\begin{array}{c}\text { Range, } \\
\text { unit }\end{array}$} & \multicolumn{4}{|c|}{ Study groups, number (n) } & \multirow[b]{2}{*}{$\begin{array}{l}\text { Reliability } \\
\text { of difference } \\
\text { (p) }\end{array}$} \\
\hline & $\begin{array}{c}\text { Control } \\
\text { group } \\
(n=50)\end{array}$ & $\begin{array}{c}\text { Group I } \\
(n=39)\end{array}$ & $\begin{array}{c}\text { Group II } \\
(n=57)\end{array}$ & $\begin{array}{c}\text { Group III } \\
(n=45)\end{array}$ & \\
\hline $\begin{array}{c}\text { Iron in blood } \\
\text { serum, } \\
\mu \mathrm{mol} / 1\end{array}$ & $20,04 \pm 2,03$ & $20,75 \pm 1,94$ & $15,77 \pm 1,53$ & $8,47 \pm 0,69$ & $\begin{array}{l}\mathrm{p}_{1}>0,05 \\
\mathrm{p}_{2}<0,001 \\
\mathrm{p}_{3}<0,001 \\
\mathrm{p}_{4}<0,001 \\
\mathrm{p}_{5}<0,001\end{array}$ \\
\hline $\begin{array}{c}\text { Iron-binding } \\
\text { capacity in } \\
\text { blood serum, } \\
\mu \mathrm{mol} / 1\end{array}$ & $57,25 \pm 2,49$ & $56,52 \pm 2,37$ & $68,55 \pm 2,20$ & $88,75 \pm 2,01$ & $\begin{array}{l}\mathrm{p}_{1}>0,05 \\
\mathrm{p}_{2}<0,001 \\
\mathrm{p}_{3}<0,001 \\
\mathrm{p}_{4}<0,001 \\
\mathrm{p}_{5}<0,001\end{array}$ \\
\hline $\begin{array}{c}\text { Unsaturated } \\
\text { iron-binding } \\
\text { capacity of } \\
\text { blood serum, } \\
\mu \mathrm{mol} / \mathrm{l}\end{array}$ & $37,21 \pm 4,31$ & $36,77 \pm 4,07$ & $39,78 \pm 3,53$ & $80,28 \pm 1,19$ & $\begin{array}{l}\mathrm{p}_{1}>0,05 \\
\mathrm{p}_{2}<0,001 \\
\mathrm{p}_{3}<0,001 \\
\mathrm{p}_{4}<0,001 \\
\mathrm{p}_{5}<0,001\end{array}$ \\
\hline $\begin{array}{l}\text { Saturation of } \\
\text { transferrin with } \\
\text { iron, } \\
\% \\
\end{array}$ & $35,18 \pm 4,90$ & $36,88 \pm 4,74$ & $32,17 \pm 3,63$ & $9,54 \pm 0,43$ & $\begin{array}{l}\mathrm{p}_{1}>0,05 \\
\mathrm{p}_{2}<0,001 \\
\mathrm{p}_{3}<0,001 \\
\mathrm{p}_{4}<0,001 \\
\mathrm{p}_{5}<0,001\end{array}$ \\
\hline $\begin{array}{c}\text { Blood serum } \\
\text { transferrin, } \\
\text { g / } 1\end{array}$ & $3,23 \pm 0,10$ & $2,90 \pm 0,09$ & $2,78 \pm 0,09$ & $4,02 \pm 0,23$ & $\begin{array}{l}\mathrm{p}_{1}<0,05 \\
\mathrm{p}_{2}<0,001 \\
\mathrm{p}_{3}<0,001 \\
\mathrm{p}_{4}<0,001 \\
\mathrm{p}_{5}<0,001\end{array}$ \\
\hline $\begin{array}{l}\text { Blood serum } \\
\text { ferritin, } \\
\\
\mu \mathrm{g} / 1\end{array}$ & $43,92 \pm 7,75$ & $86,91 \pm 9,14$ & $134,19 \pm 11,11$ & $8,03 \pm 1,98$ & $\begin{array}{l}\mathrm{p}_{1}<0,05 \\
\mathrm{p}_{2}<0,001 \\
\mathrm{p}_{3}<0,001 \\
\mathrm{p}_{4}<0,001 \\
\mathrm{p}_{5}<0,001\end{array}$ \\
\hline
\end{tabular}

Note: $\mathrm{p}_{1}$ - the reliability of difference between the ranges of the control group and group I;

$\mathrm{p}_{2}-$ the reliability of difference between the ranges of the control group and group II;

$\mathrm{p}_{3}$ - the reliability of difference between the ranges of the control group and group III;

$\mathrm{p}_{4}$ - the reliability of difference between the ranges of the group I and group II;

$\mathrm{p}_{5}$ - the reliability of difference between the ranges of the group II and group III.

From the data in table 1, it is seen that the content of iron in blood serum in the control group, on average, was $(20,04 \pm 2,03) \mu \mathrm{mol} / 1$. This range for men, on average, was $(20,75 \pm 1,94) \mu \mathrm{mol} / 1$, with individual fluctuations from 17,30 to $24.60 \mu \mathrm{mol} / 1$, and for women - $(18,77 \pm 1,53) \mu \mathrm{mol} / \mathrm{l}$, with individual fluctuations from 16,40 to $21,30 \mu \mathrm{mol} / 1$. The content of iron in blood serum for men of the control group was higher than for women 
$(\mathrm{p}<0,01)$. The results of our study show that patients in groups II and III had a significant decrease in the content of iron in blood serum $(p<0,001)$.

The range of iron-binding capacity in blood serum in the control group, on average, was $(57,25 \pm 2,49) \mu \mathrm{mol} / 1$. For men, on average, it was $(56,52 \pm 2,37) \mu \mathrm{mol} / 1$, and for women $(58,55 \pm 2,20) \mu \mathrm{mol} / 1$, with individual fluctuations for men - from 52,05 to $61,03 \mu \mathrm{mol} / 1$, and for women - from 54,87 to $62,05 \mu \mathrm{mol} / 1$. The range of iron-binding capacity in blood serum for women of the control group was higher than for men $(p<0,01)$. We found that patients of groups II and III had a significantly lower range of iron-binding capacity in blood serum, which reflects the presence of iron metabolism disorders $(\mathrm{p}<0,001)$.

The range of unsaturated iron-binding capacity of blood serum for men of the control group, on average, was 35,77 $\pm 4,07 \mu \mathrm{mol} / 1$, with individual fluctuations from 28,05 to $43,37 \mu \mathrm{mol} / 1$, and for women $-39,78 \pm 3,53 \mu \mathrm{mol} / 1$, with individual fluctuations from 34,18 to $45,65 \mu \mathrm{mol} / 1$. In general, in the control group, the rate of unsaturated iron-binding capacity was $37,21 \pm 4,31 \mu \mathrm{mol} / 1$, for women it was higher than for men $(\mathrm{p}<0,01)$. As the analysis of our results showed, patients of groups II and III, had a significantly higher range of unsaturated iron-binding capacity of blood serum, which reflects the presence of iron metabolism disorders $(\mathrm{p}<0,001)$.

The range of saturation of transferrin with iron in the control group, on average, was $(35,18 \pm 4,90) \%$. For men, on average, it was $(36,88 \pm 4,74) \%$, and for women $-(32,17 \pm$ $\pm 3,63) \%$, with individual fluctuations for men - from 28,60 to $46,10 \%$, and for women - from 26,40 to $38,30 \%$. Men from the control group had a higher range of saturation of transferrin with iron than women $(\mathrm{p}<0,01)$. We found that patients of groups II and III, had a significantly lower range of saturation of transferrin with iron, which confirms the presence of iron metabolism disorders $(\mathrm{p}<0,001)$.

The range of blood serum transferrin in the control group, on average, was $(3,23 \pm 0,10) \mathrm{g} / \mathrm{l}$. For men, this figure averaged $(3,20 \pm 0,09) \mathrm{g} / 1$, and for women $-(3,28 \pm 0,09) \mathrm{g} / \mathrm{1}$, with individual fluctuations for men - from 2,23 to $3,38 \mathrm{~g} / 1$, and for women - from 2,24 to 3,42 $\mathrm{g} / 1$. Women from the control group had a higher range of blood serum transferrin than men had $(\mathrm{p}<0,01)$. As the analysis of our results showed, changes in the range of blood serum transferrin for patients of groups II and III compared with the control group had a multidirectional nature: for patients of group II it was significantly lower, and for patients of group III it was significantly higher $(\mathrm{p}<0,001)$. This nature of the changes indicates a violation of the synthesis and metabolism of blood serum transferrin in conditions of tumor intoxication.

The blood serum ferritin in the control group for men, on average, was $(24,91 \pm$ $\pm 2,14) \mu \mathrm{g} / 1$, with individual fluctuations from 20,64 to $30,12 \mu \mathrm{g} / 1$, and for women $-(19,19 \pm$ $\pm 1,41) \mu \mathrm{g} / 1$, with individual fluctuations from 17,15 to $21,82 \mu \mathrm{g} / 1$. In General, the range of blood serum ferritin in the control group was $(22,85 \pm 3,36) \mu \mathrm{g} / 1$. The blood serum ferritin for men in this group was higher than for women $(p<0,001)$. We found that changes in the range of blood serum ferritin for patients of groups II and III compared with the control group, also had a different nature: for patients of group II it was significantly higher and for patients of group III significantly lower $(p<0,001)$. This nature of the changes is that since blood serum ferritin is an acute-phase protein and in conditions of tumor intoxication, its level increases.

It is quite natural that analyzing the obtained data, we considered it necessary to investigate how the ferritin level changes, depending on the severity of the anemic syndrome in patients with urotelial bladder cancer having malignant neoplasm anemia. The data is presented in table 2 . 
Table 2

The range of blood serum ferritin in patients with urothelial bladder cancer (UBC)
with concomitant malignant neoplasm anemia (MNA)
depending on the severity of anemia $(\mathrm{M} \pm \mathrm{m}), \boldsymbol{\mu g} / \mathrm{l}$

\begin{tabular}{|c|c|c|}
\hline \multicolumn{2}{|c|}{ Groups of patients, (n) } & \multirow{2}{*}{$\begin{array}{c}\text { Reliability of difference, } \\
\text { (p) }\end{array}$} \\
\hline Control group $(n=50)$ & Patients with UBC having MNA (n=57) & \\
\hline \multirow{4}{*}{$(43,92 \pm 7,75)$} & $\begin{array}{l}\text { mild anemia }(\mathrm{n}=29) \\
\qquad(88,98 \pm 11,15)\end{array}$ & $\begin{array}{l}\mathrm{p}_{1}<0,05 \\
\mathrm{p}_{2}>0,05 \\
\mathrm{p}_{4}>0,05 \\
\mathrm{p}_{5}<0,05 \\
\mathrm{p}_{6}<0,001\end{array}$ \\
\hline & $\begin{array}{l}\text { moderate anemia }(\mathrm{n}=12), \\
\qquad(122,89 \pm 15,87)\end{array}$ & $\begin{array}{l}\mathrm{p}_{1}<0,05 \\
\mathrm{p}_{2}<0,05 \\
\mathrm{p}_{3}>0,05 \\
\mathrm{p}_{5}<0,05 \\
\mathrm{p}_{6}<0,01\end{array}$ \\
\hline & $\begin{array}{l}\text { severe anemia }(n=10) \\
\qquad(134,19 \pm 14,19)\end{array}$ & $\begin{array}{l}\mathrm{p}_{1}<0,05 \\
\mathrm{p}_{2}<0,05 \\
\mathrm{p}_{3}<0,05 \\
\mathrm{p}_{4}<0,05 \\
\mathrm{p}_{6}<0,01\end{array}$ \\
\hline & $\begin{array}{l}\text { life-threatening anemia }(n=6) \text {, } \\
\qquad(143,28 \pm 7,11)\end{array}$ & $\begin{array}{l}\mathrm{p}_{1}<0,01 \\
\mathrm{p}_{2}<0,01 \\
\mathrm{p}_{3}<0,05 \\
\mathrm{p}_{4}<0,01 \\
\mathrm{p}_{5}<0,01\end{array}$ \\
\hline
\end{tabular}

Note: $\mathrm{p}_{1}$ - the reliability of difference compared with the control group; $\mathrm{p}_{2}-$ the reliability of difference reliability of differences with patients of group II; $\mathrm{p}_{3}$ - the reliability of difference with patients who had a mild course of anemia; $p_{4}$ - the reliability of difference with patients who had an average course of anemia; $p_{5}$ - the reliability of difference with patients who had a severe course of anemia; $p_{6}$-the reliability of difference with patients who had a course of life-threatening anemia.

As can be seen from the data in Table 2, the range of ferritin in the blood serum increases in proportion to the severity of anemia in patients with urothelial bladder cancer with concomitant anemia of malignant neoplasm. It means that the degree of life-threatening anemia in patients with urothelial bladder cancer with concomitant malignant neoplasm anemia is accompanied by a significant increase in the range of ferritin in the blood serum, which is obviously a reflection of the peculiarities of its metabolism in the tumor process.

In clinical practice, the range of ferritin is widely used to assess iron deposition. It is well known that a decrease of ferritin in blood serum is an early sign of latent iron deficiency. In combination with changes in other parameters of iron, it may indicate the presence of iron deficiency anemia. A sharp increase of ferritin in blood serum may indicate hemochromatosis or posttransfusion hemosiderosis. The normal level of ferritin in blood serum in the presence of sideropenic and anemic syndromes may indicate a violation of the processes of iron utilization in erythroid progenitor cells $[1 ; 3]$. 
Recently, other physiological functions of ferritin that are not directly related to iron metabolism have been identified. Ferritin can have a cytotoxic effect on some cells, primarily myeloid progenitor of granulocytes, monocytes. It was found that the processes of myelosuppression are correlated with the activation of the synthesis of H-subunits at the genome level. H-ferritin can block the proliferation of both myeloid and lymphoid cells. It is thought that this process may be protective to prevent malignant growth. The mechanism of ferritin suppression of cell proliferation is associated with its ferroxidase properties. The process of oxidation of iron from $\mathrm{Fe}^{2+}$ to $\mathrm{Fe}^{3+}$ is accompanied by the transfer of electrons to molecular oxygen, by the formation of various oxygen radicals, which are cytotoxic agents. The inhibition of proliferation occurs at the level of the S-phase of the cell cycle. Interestingly, ferritin suppresses normal myeloid progenitor cells and does not suppress progenitor cells in leukemia patients. L-subunits of ferritin do not have ferroxidase and myelosuppressive properties. They are attributed to the functions of stabilizers of the ferritin structure (Wick, 1995, Popovych, 2020).

The level of ferritin increases significantly in acute inflammatory processes, it is considered as an acute-phase protein with expressive cytotoxic and cytotropic properties. The level of ferritin in the blood serum increases in the presence of different types of tumors in the body: ovarian cancer, prostate, pancreas, lung, rectum, hepatocellular carcinoma, etc (Green, 2014, Titov, 2018). The concentration of ferritin increases in various liver diseases (hepatitis, cirrhosis, etc.), which are accompanied by the destruction of hepatocytes. In this case, ferritin is directly released from the liver cells, which is its depot. Therefore, an increase of ferritin in blood serum may be both a tumor marker and a sign of liver disease.

\section{Conclusions}

1. The range of ferritin in the blood serum is an important laboratory diagnostic criterion in modern clinical practice, which reflects the state of the deposited iron in the body. Ferritin is an acute-phase protein, its definition has both diagnostic and differential diagnostic value in the study of disorders of iron metabolism, in particular, in anemia of malignant neoplasms in patients with urothelial bladder cancer, and iron deficiency anemia, since changes in the range of blood serum ferritin in these diseases are multidirectional.

2. New data on the functions of ferritin and its participation in metabolism indicate that the determination of its range in various diseases is a promising area of laboratory research in oncology and hematology practice.

\section{References}

Andriiaka, A. A. (2018). Anemia zlokachestvennogo obrazovanija: osobennosti vedenija pazientov [Anemia of malignant neoplasm: peculiarities of patient management]. Hematologija. Transfusiologija. Vostochnaja Evropa - Hematology. Transfusiology. Eastern Europe, 2, 223 - 229 [in Russian].

Green, J. P. (eds.) (2014). Wintrobe's clinical hematology. Philadelphia: Lippincott Williams\&Wilkins.

Fedorenko, Z. P., Kolesnik, O. O., Gulak, L. O. (2019). Cancer in Ukraine, 2017-2018. Morbidity, mortality, indicators of efficiency of oncology service. Bulletin of the National Cancer Registry of Ukraine. Issue No. 20. Kyiv: PE Polyum. 
Khalafian, A. A. (2014) Sovremennye statisticheskije metody v medizinskih issledovanijach: monografija [Modern statistical methods of medical research: monograph]. Moskow, Russia: N. p. [in Russian].

Linchevskii, O. V., Kovaliov, O. O., Kolesnyk, O. O., Beznosenko, A. P. (2019) Zlojakisni novoutvorennja v Ukraini (analityko-statystychnyi dovidnyk) [Malignant neoplasms in Ukraine (analytical and statistical reference book)]. Praktycna onkologia - Practical Oncology. 2, 59-118 [in Ukrainian].

Popovych, M. Yu. (2020). Zhelezodefizitnaia anemia: ozenka statusa zheleza v organizme po urovniu syvorotochnogo ferritina s uchetom rekomendazii VOZ (2020) [Iron deficiency anemia: Assesment of iron status in the human body by serum ferritin level, taking into account WHO recommendations (2020)]. Hematologija. Transfusiologija. Vostochnaja Evropa-Hematology. Transfusiology. Eastern Europe, 4, 479-488 [in Russian].

Titov, E. V. (2018). Sovremennyje metody diagnostiki i prognosa urotelialnogo raka mochevogo pusyria [Modern methods of diagnosis and prognosis of urothelial bladder cancer]. Problemy bezperervnoi medychnoi osvity ta nauky - Problems of Uninterrupted Medical Training and Science, 2, 86-91 [in Russian].

Wick, M., Pinggera, W., Lehmann, P. (1995). Ferritin in iron metabolism: Diagnosis of anemias (2nd ed. rev.). Wien, New York: Springer. 